\title{
Verbs and Their Thematic Role Processing Abilities for People with Aphasia
}

\author{
Kwi Hyun Jeonga, Jee Eun Sung ${ }^{\mathrm{a}}$ \\ ${ }^{a}$ Department of Communication Disorders, Ewha Womans University, Seoul, Korea
}

Correspondence: Jee Eun Sung, PhD Department of Communication Disorders, Ewha Womans University, 52 Ewhayeodae-gil, Seodamun-gu, Seoul 03760, Korea

Tel: $+82-2-3277-2208$

Fax: +82-2-3277-2122

E-mail: jeesung@ewha.ac.kr

Received: April 5, 2018

Revised: May 18, 2018

Accepted: May 18, 2018

This work was supported by the Ministry of Education of the Republic of Korea and the National Research Foundation of Korea (No. NRF2017R1A2B4006604)

\begin{abstract}
Objectives: The purpose of this study was to investigate the ability of people with aphasia (PWA) to process verbs and their thematic roles. We further examined the relationship between verb-related processing abilities and aphasia severity. Methods: Fifteen individuals with aphasia and 15 age- and education-matched normal individuals participated in the study. Experiment conditions consisted of thematic role-selection tasks (agent-selection vs. theme-selection) and verb-selection tasks when the two thematic roles were provided. Participants were asked to select the target among 3 choices. Results: PWA performed significantly worse in all conditions than normal elderly adults (NEA). Both groups performed worse on the agent-selection than theme-selection tasks. The group by thematic-role type interaction was significant, indicating that PWA demonstrated differentially greater difficulties in the agent-selection than theme-selection task compared to the NEA group. The verbselection task was highly correlated with overall aphasia severity and verbal output measures from the standardized aphasia battery. Conclusion: These results indicated that PWA demonstrated deficits in selecting thematic roles associated with the verbs and choosing the verbs when the thematic roles were provided. Greater difficulties in the agent-selection than theme-selection task in both groups are likely due to the pro-drop phenomena, usually associated with the subject-deletion features in Korean. Overall high correlations of verb-selection task with aphasia severity and verbal output measures indicate that the verb-selection task may be a clinically useful method to evaluate word retrieval process deficits in PWA without using an overt naming task.
\end{abstract}

Keywords: Aphasia, Verb, Thematic role
동사는 문장을 구성하는 데 가장 중심적인 서술어의 기능을 하는 품사로(Kwon, 2009) 문장 안에서 중요한 의미를 전달한다(Wambaugh, Doyle, Martinez, \& Kalinyak-Fliszar, 2002). 또한, 동사는 의미적인 측면뿐만 아니라 문법적으로도 중요한 기능을 담당하는 품사로서 주로 명사구와 결합하여 문장을 구성하며, 명사구와의 결합은 동사와 명사구 사이의 의미적인 관계를 바탕으로 이루어진 다(McRae, Hare, Elman, \& Ferretti, 2005). 예를 들어, '먹다'라는 동사가 제시되었을 때, ‘무엇을 먹는가?' 그리고 ‘누가 먹는가?'와 같 은 추가적인 정보를 필요로 한다. '무엇'에 해당하는 동사의 대상 (theme)은 밥, 과일, 채소 등, 먹을 수 있는 음식과 관련한 명사를 예 상할 수 있으며, '누구'에 해당하는 동사의 행동주(agent)로는 사람
이나 동물 등 먹는 주체가 되는 생물 명사를 예상할 수 있다. 즉, 동 사의 대상 및 행위자와 같이 동사와 관련된 의미 정보를 제공해주 는 문장의 구성 요소를 동사의 '의미역(thematic role)'이라고 한다 (Seo, Ko, Yoo, \& Kim, 2000). 동사의 의미역에는 '행위자' 및 '대상' 외에도 '도구(instrument), 처소(location), 도달점(goal), 원천 (source)' 등 다양한 유형이 있다(Hong, 1998; Saeed, 1997; Seo et al., 2000). 본 연구에서는 이 중에서도 동사에서 가장 주요한 의미 역으로 알려진 '행위자' 및 '대상'에 해당하는 의미역에 국한하여 실어증 환자의 의미역 처리 양상 및 동사 재인에 대한 수행력을 살 펴보고자 하였다.

의미역에 관한 선행연구들을 살펴보면, 대부분 동사와 의미역의 
관계에 영향을 미치는 요소에 대하여 알아보고자 하였다. McRae, Ferretti와 Amyote (1997)는 의미역을 활성화하는 네트워크는 일상 적으로 접하는 경험과 세상에서 얻어지는 지식을 통해 이루어진다 는 이론을 보고했다. 이 이론에 따르면 동사를 듣거나 읽을 때, 이와 관련된 상황이나 의미 지식이 활성화되고, 이에 따라 동사와 관련된 의미역에 관한 기억체계가 조직화된다고 주장하였다. 하지만, 동사가 일반적인 상황이나 의미 지식에 의존한다는 이론과 반대로 '동사 특 정 지식(verb-specific knowledge)'에 의존하여 문장 내에서 동사처리 가 일어난다는 내용을 보고한 연구도 있다. Dickey와 Warren (2015) 의 실어증 환자를 대상으로 한 동사 의미역 처리 관련 연구에 따르면, '사건 관련 세상 지식(event-related world knowledge')은 동사와 논항 통합에 중요한 요소로 작용되지 않았고, 이보다는 동사 특정 지식이 실어증 환자의 동사 의미역 처리에 영향을 미치는 것으로 나타났다.

동사의 의미역은 주로 명사구로 이루어져 있고, 명사구와 결합 하여 문장을 형성하는 데 중요한 역할을 하는 주요 성분이 동사와 그 의미역인만큼, 실어증 환자의 언어 중재에서도 이에 대한 관심이 부각되고 있다. 동사의 의미역을 강화하여 동사 산출 및 문장 산출 에서의 일반화 효과까지 기대할 수 있다는 이론에 근거하여 개발된 대표적인 실어증 중재방법이 동사의미역강화중재(verb network strengthening treatment; Edmonds, Nadeau, \& Kiran, 2009)이다. 동사의미역강화중재는 동사와 두 가지의 의미역 유형(행위자 및 대 상)을 이용하여 실어증 환자의 어휘 산출 능력 향상을 목표로 한 중재방법이다. 중재 결과, 중재에 사용된 목표 동사뿐 아니라 중재 에서 사용되지 않았으나 목표 동사와 의미가 관련 있는 동사, 그리 고 의미역에 해당하는 명사산출 능력까지 일반화 되었다(Edmonds et al., 2009). 국내에서도 Kwag, Sung, Kim과 Cheon (2014)이 동사 의미역강화중재를 한국 실어증 환자를 대상으로 시행한 결과 Edmonds 등(2009)의 연구와 동일한 결과가 보고되었다. 즉, 의미역을 활용한 동사 중재는 동사뿐만 아니라 명사 이름대기에까지 일반화 효과가 나타나는 효율적인 중재방법일 수 있으며, 따라서 동사의 의미역에 대한 기초 연구가 다양하게 진행될 필요가 있다.

한국어 사용 실어증 환자에게도 동사의 의미역 활성화가 중재에 효과적일 수 있다는 근거가 보고되었으나, 여전히 한국 실어증 환 자들을 대상으로 동사의 의미역을 세분화하여 의미역 유형이 미치 는 영향에 대한 연구는 부족한 실정이다. 지금까지 한국 실어증 환 자의 동사 능력과 관련 선행연구들을 살펴보면, 명사 및 동사의 품 사별 재인 능력 차이(Hyun, Kim, Shin, \& Seo, 2003)에 대한 연구나 동사 논항(Choi \& Sung, 2014; Kim, 2006; Sung, 2016; Yang, 2015) 과 같이 동사의 통사적, 문법적인 부분들에 대한 연구가 진행되어 왔다. 동사의 논항이란 문장의 서술어인 동사와 함께 문장을 구성
하는 데 필수적인 성분을 말한다(Nam, 2007). 논항 구조는 서술어 가 문장을 구성하면서 필요로 하는 의미역의 집합으로, 논항은 동 사에 대한 의미적인 정보를 제공하며 의미관계를 문법적으로 구조 화하는 단위이다(Nam, 2007). 즉, 의미역은 동사와 관련된 의미론 에 근거한 개념이라면, 논항은 의미역을 가지는 명사구 간의 문법 구 조를 형성하는 것으로 통사적인 개념으로 볼 수 있다(Saeed, 1997). 실어증 환자의 동사와 관련된 연구들은 논항 구조가 동사 재인 에 미치는 영향을 다양하게 보고한 바 있다. 영어권 실어증 환자를 대상으로 한 Kim과 Thompson (2000)의 연구에서는 1항, 2항, 3항 동사 간 실어증 환자들의 동사 산출 능력이 유의한 차이를 보였으 나 국내에서 실시된 Kim (2006), Yang (2015) 연구에서는 1항과 2 항 동사 사이에는 실어증 환자의 동사 산출 능력에 유의한 차이가 없었으나 3 항 동사와는 유의한 차이를 보였다. 이러한 차이는 실어 증 환자들이 동사를 처리할 때 주어 생략의 영향을 받은 결과이다 (Kim, 2006). 또한 Sung (2016) 연구에서도 실어증 환자의 동사 산 출 능력이 1 항 동사와 3 항 동사 사이에만 유의한 차이를 보이고 2 항 동사와 유의한 차이를 보이는 동사는 없었다. 이러한 결과에 대하 여 Sung (2016) 또한 선행연구와 동일하게 빈번한 주어 생략의 영향 을 받은 결과라고 밝혔다. 특히, 주어 생략 현상은 1 항 동사를 사용 할 때 보다 2항, 3항 동사를 사용할 때 더 두드러지게 나타났다. 이 러한 주어 생략의 영향은 한국어가 주어-목적어-동사의 구조로 동 사가 문장을 완성하는 동사 중심의 언어이기 때문에(Nam, 2004) 명사는 상대적으로 중요도가 낮고, 이러한 이유로 한국어에서는 생략이 나타나는데, 그 중에서도 주어 생략이 가장 많이 나타난다 고 밝힌 Park (2013)의 연구와 일치하는 결과이다. 즉, 한국어 특징 적인 언어적 현상이 실어증 환자의 동사 관련 통사적 처리에 영향 을 줄 수 있음을 알 수 있다. 하지만, 동사의 의미 구조와 관련된 의 미역 처리에 대한 연구는 매우 드물다. 따라서, 본 연구에서는, 한국 실어증 환자를 대상으로 의미역 유형을 달리 하였을 때, 동사와의 관련성에 근거하여 의미역을 처리하는 능력이 어떠한지 알아보고 자 하며, 또한, 의미역이 제시되었을 때, 이에 근거하여 동사를 선택 하는 능력에 문제가 있는지 살펴보고자 한다. 이러한 동사 의미역 관련 처리 능력이 실어증의 중증도와도 어떠한 관계가 있는지 살펴 보는 것이 중요할 것으로 예상되어, 이와 관련된 결과도 함께 살펴 보았다. 구체적인 연구 질문은 아래와 같다.

1) 동사 제시 후, 의미역 유형(행위자 vs. 대상)에 따라 의미역 선 택 정확도에서 실어증 환자 및 정상군 간 차이가 유의한가?

2) 두 개의 의미역을 제시 후, 동사 선택 정확도에서 실어증 환자 및 정상군 간차이가 유의한가?

3) 실어증 환자 집단에서 의미역 선택 정확도와 동사 선택 정확도 
간 상관관계가 어떠한가? 또한, 두 가지 의미역 선택(행동주 vs. 대상) 과제 중, 동사 선택 과제를 유의하게 예측하는 변수는 무 엇인가?

4) 실어증 환자 집단에서 의미역 선택 정확도 및 동사 선택 정확 도가 전반적인 실어증 중증도와의 상관관계는 어떠한가?

\section{연구방법}

\section{연구대상}

본 연구는 정상 성인 15 명과 실어증 환자 15 명을 대상으로 실시 하였다. 두 집단 모두 오른손잡이며, 한국어를 모국어로 사용하는 자로 선정하였다.

실어증 환자는 (1) 좌뇌반구 단일부위로 피질 및 피질하 영역에 뇌졸중으로 기인한 언어장애를 보이는 자, (2) 파라다이스-한국판웨스턴 실어증검사 개정판(Paradise-Korean version the Western Aphasia Battery Revised, PK-WAB-R; Kim \& Na, 2012)을 통해 실 어증으로 판단된 자, (3) 발병 이전에 뇌손상 및 기타 신경학적 질환 이 없다고 보고된 자, (4) PK-WAB-R 하위영역 중 읽기영역에서 단 어-실물 짝짓기, 단어-그림 짝짓기, 그림-단어 짝짓기 과제를 모두 정반응한 자, (5) 연령과 교육수준 차이가 수행력에 미치는 영향을 최소화하기 위하여 75 세 이하이며, 초등학교 졸업 이상의 학력을 갖춘 자(Kang, Chin, Na, Lee, \& Park, 2000)를 대상자로 선정하였 다. 실어증 환자의 중증도에 대한 정보는 Table 1에 제시하였다.

정상 성인은 (1) 실어증 환자 집단과 평균 연령 및 평균 교육연수
가 일치하는 자, (2) 한국형 간이정신상태검사(Korean-Mini Mental State Examination, K-MMSE; Kang, Na, \& Hahn, 1997) 실시 결과, 정상 범위 $(>16 \%$ ile)에 해당하는 자, (3) 그 외에 언어 및 신경학적 손 상, 병력이 보고되지 않은 자를 대상자로 선정하였다. 두 집단 간 연 령 및 교육연수에서 유의한 차이가 있는지 살펴보기 위해 독립표본 $t$-검정(two-independent samples $t$-test)을 실시한 결과, 연령 및 교육 연수에서 집단 간 차이가 유의하지 않은 것으로 나타났다(Table 2).

\section{실험 과제}

\section{동사 선정}

행위자 및 대상을 동사의 문장 필수 성분을 가지는 2 항 동사 총 15 개를 선정하였다. 구체적인 동사 선정 기준은 (1) 행위자와 대상 이 필수 논항인 2항 동사, (2) 현대 한국어의 어휘 빈도(Seo, 1998)에 서는 100 이하를 저빈도, 100 에서 1,000 이하를 고빈도, 1,000 이상 을 최고빈도라고 정의하여 이를 기준으로 100 이상의 고빈도 및 최 고빈도 동사, (3) 단어의 길이가 명사와 동사의 산출에 영향을 미친 다는 연구(Best, 1995; Jung, Choi, \& Hwang, 2014)에 따라 동사 기 본형이 1-3음절로 구성된 동사이다. 동사 제외 기준은 (1) 행위자와

Table 2. Result of two-independent samples t-test on age and education

\begin{tabular}{lcccc}
\hline & Normal $(\mathrm{N}=15)$ & Aphasic $(\mathrm{N}=15)$ & $t$ & $p$-value \\
\hline Age (yr) & $53.46(11.33)$ & $51.53(10.68)$ & -.481 & .634 \\
Years of education & $13.66(2.49)$ & $13.06(2.91)$ & -.605 & .550 \\
\hline
\end{tabular}

Values are presented as mean (SD).

Table 1. Descriptive information of participants with aphasia

\begin{tabular}{|c|c|c|c|c|c|c|c|}
\hline \multirow{2}{*}{ Age (yr)/Sex } & \multirow{2}{*}{ Aphasia quotient } & \multicolumn{2}{|c|}{ Spontaneous speech } & \multirow{2}{*}{ Comprehension } & \multirow{2}{*}{ Repetition } & \multirow{2}{*}{ Naming } & \multirow{2}{*}{ Type } \\
\hline & & Contents & Fluency & & & & \\
\hline $37 / M$ & 42.1 & 2 & 4 & 7.65 & 4.6 & 2.8 & Broca \\
\hline $32 / \mathrm{M}$ & 71.5 & 4 & 8 & 7.65 & 9.4 & 6.7 & Broca \\
\hline $56 / \mathrm{M}$ & 66.1 & 4 & 8 & 7.85 & 9.7 & 3.5 & Transcortical motor \\
\hline $48 / F$ & 63.7 & 6 & 8 & 7.55 & 4.5 & 5.8 & Conduction \\
\hline $55 / F$ & 80 & 8 & 9 & 5 & 9.7 & 8.3 & Transcortical sensory \\
\hline $54 / \mathrm{M}$ & 49.3 & 5 & 5 & 4.05 & 8.8 & 1.9 & Transcortical sensory \\
\hline 49/M & 77.1 & 6 & 8 & 8.95 & 7.4 & 8.2 & Anomic \\
\hline $57 / M$ & 64.6 & 5 & 8 & 6.9 & 5 & 7.4 & Broca \\
\hline 48/M & 52.6 & 6 & 6 & 6.4 & 5.2 & 2.7 & Conduction \\
\hline $48 / F$ & 55.6 & 5 & 6 & 7.9 & 3.2 & 5.7 & Conduction \\
\hline $42 / \mathrm{M}$ & 77.4 & 6 & 8 & 8 & 8.6 & 8.1 & Anomic \\
\hline $73 / F$ & 28.6 & 5 & 5 & 3 & .8 & .5 & Wernicke \\
\hline $53 / \mathrm{M}$ & 39.6 & 3 & 5 & 6.2 & 1.4 & 4.2 & Broca \\
\hline $51 / \mathrm{M}$ & 35.4 & 3 & 6 & 5 & .8 & 2.9 & Broca \\
\hline $71 / F$ & 84.6 & 6 & 9 & 9.8 & 10 & 7.5 & Anomic \\
\hline
\end{tabular}


대상이 서로 바뀔 수 있는 가역적 동사, (2) ‘대상’ 위치에 추상 명사 를 취하는 동사, (3) 어떠한 명사가 대상으로 오더라도 의미 연결이 가능한 동사(예: '(사진을) 찍다'라는 동사와 같이 찍을 수 있는 피 사체가 거의 모든 구체 명사가 가능한 동사의 경우)는 제외하였다.

이렇게 선정된 15 개의 동사로 의미적으로 관련성이 높은 명사구 를 선택하여 문장을 제작하였다. 문장은 '주어-목적어-동사' 구조로, 주어는 '행위자(agent)'를 목적어는 '대상(theme)'을 의미역으로 구성 하여, 동사와 결합하였을 때 의미적으로 관련이 있고, 자연스러운 문 장으로 제작하였다. 실험 자극은 Appendix 1에 모두 제시하였다.

\section{과제 제작}

의미역 선택 과제

의미역 선택 과제는 크게 행위자 선택 과제와 대상 선택 과제 두 가지 유형으로 구성된다. 행위자 선택 과제에서는 행위자에 해당 하는 칸이 빈칸으로 제시되며 행위자임을 표시하는 문법적 지표로 서 주격 조사(이/가)와 함께 목표 동사를 제시하였다. 예를 들어, '깎다' 동사 문항의 경우" 가 깎다'로 과제를 제시하였다. 피험 자에게 이 문장 아래에 제시된 세 개의 단어 중 적절한 단어 하나를 선택하도록 하였다. 세 개의 보기에 포함된 단어는 다음과 같다.

(1) 목표 단어(행위자, 예: 엄마),

(2) 무관련 단어(생물 명사, 예: 고추),

(3) 무관련 단어(무생물 명사, 예: 기차).

대상 선택 과제에서는 대상에 해당하는 칸이 빈칸으로 제시되며 대상임을 표시하는 문법적 지표로서 목적격 조사(을/를)와 함께 목표 동사를 제시하였다. 위에서 제시된 예시와 동일하게 '깎다' 동 사 문항의 경우 '____를 깎다'로 과제를 제시하였다. 피험자에게 이 문장 아래에 제시된 세 개의 단어 중 적절한 단어 하나를 선택하도 록 하였다. 세 개의 보기에 포함된 단어는 다음과 같다. 의미역 선택 과제 예시는 Appendix 2에 제시하였다.

(1) 목표 단어(대상, 예: 참외),

(2) 무관련 단어(생물 명사, 예: 상추),

(3) 무관련 단어(무생물 명사, 예: 모자).

\section{동사선택 과제}

동사 선택 과제는 행위자와 대상의 의미역 두 개가 모두 제시 된 상태에서 동사를 선택하는 것이다. 예를 들어, 동사 '깎다'가 목표 문항인 경우 ‘엄마가 참외를 '로 과제를 제시한 후, 문장 아래 에는 목표 동사('먹다')와 무관련 2항 동사 2개(예: '속이다', '끄다') 를 포함하여, 총 3 가지 동사 중 하나를 선택하도록 하였다. 동사 선 택 과제 예시는 Appendix 3에 제시하였다.

\section{연구 절차}

실험은 독립된 조용한 방 안에서 실시하였다. 실험하기 전, 연습 문항을 통해 대상자들에게 실험과제를 충분히 숙지시킨 후 본 과 제를 실시하였다. 의미역 선택 과제 내에서 행위자 및 대상자 선택 과제 2가지 제시 순서를 역균형화(counter-balance)하여 실시하였 고, 동사 선택 과제는 의미역 선택 과제가 모두 끝난 후, 마지막에 실 시하였다. 모든 자극은 $\mathrm{A} 4$ 용지 사이즈의 책자를 통해 총 45 개의 문 항을 한 문항씩 제시하였다. 반복적인 제시로 인한 학습효과를 줄 이기 위해 Sung (2011)의 단어 바로 및 거꾸로 따라말하기 작업기 억 과제를 추가로 실시하였다. 따라서 의미역 선택 과제(1), 단어 바 로 따라말하기 과제, 의미역 선택 과제(2), 단어 거꾸로 따라말하기 과제, 동사 선택 과제 순서로 실험을 진행하였다.

각 과제마다 대상자에게 "제시된 문장을 보시고, 빈칸에 들어갈 수 있는 단어를 아래에 있는 세 단어 중 선택하여 주세요”라고 지시 하였다. 만약 대상자가각 문항에서 지시를 들은 후 15 초 동안 반응을 보이지 않으면 “이 단어 앞에(또는 뒤에) 들어갈 수 있는 단어가 무엇 인가요? 아래에 있는 세 개의 단어 중 선택하여 주세요"라고 다시 지 시를 제공한 후 반응을 기다렸다. 대상자가 2 번의 지시 제공 후에도 반응을 보이지 않으면 오반응 한 것으로 간주하고 다음 문항으로 넘 어갔다. 1 번부터 15 번까지 총 3 개의 과제를 순서대로 한 문항씩 실시 하였으며, 하나의 과제가 끝나면 잠시 쉬는 시간을 제공하여 피로 효 과를 감소하였다. 대상자에게 의미적, 음소적, 시각적으로 단서를 제 공하지 않았고, 반응에 대한 정반응 또는 오반응인지 대한 피드백을 제공하지 않았다. 대상자의 모든 반응은 결과 기록지에 기록하였다.

\section{자료 분석}

대상자가 보기에 제시된 세 개의 어휘 중 적절한 어휘를 선택한 경우 정반응으로 처리하였으며, 실험을 실시하는 동안 아무 반응 을 보이지 않은 경우(no response, NR), 모른다고 답한 경우(don't know, DK), 부적절한 답을 선택한 경우는 모두 오반응으로 처리하 였다. 각 문항별로 정반응한 문항은 1 점, 오반응한 문항은 0 점으로 계산하여 총 합계를 구하였다. 각 과제마다 산출된 합계를 총 문항 수인 15 로 나눈 후 100 을 곱하여 정반응률(\%)을 계산하였다.

\section{연구결과}

\section{의미역 선택 과제 유형(행위자 vs. 대상)에 따른 집단 간 정반응률 분석}

행위자와 대상에서 모두 실어증 환자보다 정상 성인 집단의 정반 응률이 더 높게 나타났다. 집단 내에서 의미역 유형별 차이를 살펴 
보면, 실어증 환자의 경우 행위자 선택 과제보다 대상 선택 과제에 서 더 높은 정반응률이 나타났다. 정상 성인에서도 행위자보다 대 상에서 더 높은 정반응률이 나타났다. 의미역 유형에 따른 집단 간 정반응률에 대한 기술통계 결과는 Table 3에 제시하였다.

의미역 유형에 따른 집단 간 정반응률에 대한 이원혼합분산분 석(two-way mixed ANOVA) 결과, 집단에 대한 주효과가 통계적으 로 유의하였다 $\left(F_{(1,28)}=59.933, p<.01\right)$. 즉, 정상 성인 집단의 정반응 률이 실어증 환자보다 유의하게 더 높은 것으로 나타났다.

의미역 유형에 대한 주효과가 통계적으로 유의하였다 $\left(F_{(1,28)}=\right.$ $13.049, p<.01)$. 즉, 의미역 유형 중 대상 선택 과제의 정반응률이 행 위자 선택 과제의 정반응률보다 유의하게 더 높은 것으로 나타났다.

의미역 유형에 따른 집단 간 상호작용이 통계적으로 유의하였다 $\left(F_{(1,28)}=5.176, p<.05\right)$. 즉, 의미역 유형에 따른 과제의 정반응률 차 이가 정상 성인 집단에 비해 실어증 환자에서 유의하게 더 큰 것으 로 나타났다. 즉, 실어증 환자가 행위자 선택 과제에서 대상 선택 과 제에 비해 더 큰 어려움을 보이는 것으로 나타났다(Table 4).

\section{동사 선택 과제에서 실어증 환자 및 정상군 간 정반응률 분석}

동사 선택 과제에서 집단 간 정반응률에 대한 일원분산분석 결

Table 3. Descriptive statistics of accuracy (\%)

\begin{tabular}{lcc}
\hline Thematic role type & Normal $(\mathrm{N}=15)$ & Aphasic $(\mathrm{N}=15)$ \\
\hline Agent & $95.53(8.23)$ & $55.40(15.81)$ \\
Theme & $100(0)$ & $75.06(23.36)$ \\
\hline
\end{tabular}

Values are presented as mean (SD).

Table 4. Results of two-way mixed ANOVA

\begin{tabular}{lrrrrr}
\hline & $\begin{array}{c}\text { Sum of } \\
\text { square }\end{array}$ & $\begin{array}{c}\text { Degree of } \\
\text { freedom }\end{array}$ & \multicolumn{1}{c}{$\begin{array}{c}\text { Mean } \\
\text { square }\end{array}$} & $F$ & $\begin{array}{c}p \\
\text { value }\end{array}$ \\
\hline Group & $15,876.267$ & 1 & $15,876.267$ & $59.933^{* *}$ & .000 \\
Error & $7,409.733$ & 28 & 264.633 & & \\
Thematic role type & $2,184.067$ & 1 & $2,184.067$ & $13.049^{* *}$ & .001 \\
Thematic role type Group & 866.400 & 1 & 866.400 & $5.176^{*}$ & .031 \\
Error & $4,686.533$ & 28 & 167.376 & & \\
\hline
\end{tabular}

${ }^{*} p<.05,{ }^{* *} p<.01$.
과, 실어증 환자와 정상 성인 집단에 대한 주효과가 통계적으로 유 의하였다 $\left(F_{(1,28)}=12.650, p<.01\right)$. 즉, 실어증 환자가 정상군에 비해 유의하게 수행력이 저하된 것으로 나타났다(Table 5).

\section{실어증 환자 집단에서 의미역 선택 과제와 동사 선택 과제 간 상관관계 및 회귀분석}

각 과제 간 Pearson 상관계수를 살펴본 결과, 동사 선택 과제와 대상 의미역 선택 과제의 상관관계가 $r=.886, p<.01$ 로 강한 정적 상관관계를 보였다. 그러나 동사 선택 과제와 행위자 의미역 선택 과제는 유의한 상관관계를 보이지 않았다 $(r=.155)$. 즉, 동사를 선 택하는 과제와 행위자 및 대상 의미역 선택 과제 중 대상 의미역 선 택 과제만 동사 선택 과제와 통계적으로 유의한 상관관계를 보였다 (Table 6).

행위자 선택 및 대상 선택 과제 중 실어증 환자의 동사 선택 과제 수행력을 유의하게 예측하는 변수가 무엇인지 살펴보기 위해, 단계 선택 다중 회귀분석(stepwise multiple regression analysis)을 실시 하였다. 동사 선택 과제 수행력을 종속변수로, 두 가지 의미역 선택 과제를 독립변수로 설정하였다. 그 결과, 동사 선택 과제 수행률을 유의하게 예측하는 변수는, 두 가지 의미역 선택 과제 중 대상 선택 과제인 것으로 나타났다 $\left(F_{(1,13)}=47.708, p<.0001, R^{2}=.786\right)$.

Table 5. Result of one-way ANOVA

\begin{tabular}{lcccc}
\hline & Normal $(\mathrm{N}=15)$ & Aphasic $(\mathrm{N}=15)$ & $F$ & $p$-value \\
\hline Task $\quad 99.533(1.80)$ & $73.66(28.10)$ & $12.650^{* *}$ & .001 \\
\hline $\begin{array}{l}\text { Values are presented as mean (SD). } \\
{ }^{* *} p<.01 .\end{array}$
\end{tabular}

Table 6. Results of Pearson correlation coefficients among tasks

\begin{tabular}{lccc}
\hline & $\begin{array}{c}\text { Agent selection } \\
\text { task }\end{array}$ & $\begin{array}{c}\text { Theme selection } \\
\text { task }\end{array}$ & $\begin{array}{c}\text { Verb selection } \\
\text { task }\end{array}$ \\
\hline Agent selection task & 1 & - & - \\
Theme selection task & .263 & 1 & - \\
Verb selection task & .155 & $.886^{* *}$ & 1 \\
\hline
\end{tabular}

${ }^{* *} p<.01$.

Table 7. Result of Pearson correlation coefficients among tasks and aphasia severity

\begin{tabular}{lcccrr}
\hline & A0 & Fluency & Contents & Comprehension & Repetition \\
\hline Agent selection & -.204 & .225 & -.091 & -.349 & -.178 \\
Theme selection & .510 & .451 & $.587^{*}$ & .294 & .349 \\
Verb selection & $.634^{*}$ & $.593^{*}$ & $.671^{* *}$ & .271 & .421 \\
\hline
\end{tabular}

$\mathrm{AQ}=$ aphasia quotient.

${ }^{*} p<.05,{ }^{* *} p<.01$. 


\section{실어증 환자 집단에서 동사 선택 과제와 의미역 선택 과제의 수행력과 전반적인 실어증 중증도 간 상관관계 분석}

동사 선택 과제와 의미역 선택 과제의 전반적인 실어증 중증도 (실어증 지수; aphasia quotient, $\mathrm{AQ}$ ) 및 $\mathrm{AQ}$ 하위항목 간 Pearson 상관관계를 분석하였다. 상관계수는 Table 7에 제시하였다. 의미역 선택 과제 중, 행위자 선택 과제는 실어증 중증도와 관련된 어떠한 변수와도 유의한 상관관계를 보이지 않았다. 반면, 대상 선택 과제 는 내용전달 하위항목과 유의한 정적 상관관계를 보였다 $(r=.587$, $p<.05)$. 동사 선택 과제는 실어증 지수(AQ) $(r=.634, p<.05)$, 유창 성 $(r=.593, p<.05)$, 내용전달 $(r=.671, p<.01)$ 및 이름대기 $(r=.578$, $p<.05)$ 하위항목들과 유의한 정적 상관관계를 보였다.

즉, 행위자 의미역 선택 과제는 전반적인 실어증 중증도와 유의한 상관관계도 보이지 않았으나 대상 선택 과제와 동사 선택 과제는 통 계적으로 유의한 상관관계를 보였다. 특히, 동사 선택 과제에서 실 어증 중증도와강한 상관관계를 보이는 것으로 나타났다(Table 7).

\section{논의 및 결론}

본 연구는 한국 실어증 환자를 대상으로 두 가지의 다른 의미역 유형을 제시하였을 때, 동사와의 의미적인 관련성에 근거하여 의미 역을 처리하는 능력에 대하여 알아보았다. 또한 동사의 의미역이 제시되었을 때, 이에 근거하여 동사를 선택하는 능력에 대하여 알 아보았으며, 마지막으로 동사와 의미역 관련 처리 능력이 실어증 중 증도와 어떠한 관계가 있는지 살펴보았다.

연구결과, 실어증 환자 집단은 행위자 의미역과 대상 의미역 과 제 모두 정상 성인 집단에 비해 어려움을 보이는 것으로 나타났다. 동사의 의미역을 처리하기 위해서는 의미역을 구성하는 명사구의 단어 의미에 대한 접근이 제대로 이루어져야 하며, 이 의미역이 동 사의 행동주인지 대상인지를 파악하는 통사적 단서를 통합하는 복잡한 능력이 요구된다(Friederici \& Frazier, 1992; Miyake, Carpenter, \& Just, 1994). 따라서, 실어증 환자들이 어려움을 보인 원인 은 동사 의미역을 통사구조 내에서 의미적으로 통합하는 복합적인 처리 능력 손상에 기인한 것으로 해석된다.

의미역 유형 간 차이를 살펴보면, 정상 성인 집단과 실어증 집단 모두 행위자 의미역보다 대상 의미역에서 더 높은 정반응률을 보여 두 집단 모두 행위자 의미역에 어려움이 있는 것으로 나타났다. 이 러한 결과는 한국어의 주어 생략 특성으로 설명할 수 있다. 한국어 는 동사가 문장의 마지막에 위치하는 동사 후치어의 문장구조를 가지고 있으며, 동사 앞에 위치하는 명사구가 생략이 되어도 통사 적인 오류로 인식되지 않는다. 따라서, 한국어는 주어와 목적어의
생략이 빈번하게 일어나는 통사구조를 지니고 있으며, 이러한 현상 은 정상 성인의 구어 전사자료에서 주어 생략이 가장 높은 빈도로 나타난다는 행동 결과로 뒷받침되고 있다(Park, 2013). 주어, 즉 행 위자 의미역이 되는 문장의 구성 요소가 평소 구어에서 자주 생략 된다는 것은 행위자 의미역이 동사와 관련된 의미정보를 전달하는 주요한 문장 구성요소가 아닌 것으로 해석할 수 있다. 따라서, 평소 주어 생략이 빈번하여, 행동주에 대한 문장처리에 비교적 적은 관 심과 인지적 용량을 써 온 한국어 사용자에게 행동주에 대한 선택 과제는 반대로 추가적인 인지적 요구(cognitive demands)를 반영 하는 과제일 수 있다. 이러한 특징이 두 집단 모두 행위자 의미역 선 택 과제에서 더 큰 어려움을 보인 것에 기여했을 것으로 보인다.

두 집단 모두 행위자 의미역 선택에 어려움을 보였으나 실어증 환 자군은 정상군에 비해 더 큰 어려움을 보인다는 것이 유의한 이차 상호작용에서 확인되었다. 이러한 차이는 실어증 환자들의 조사처 리 능력의 결함(Sung, Jeong, Sim, Lee, \& Mo, 2015)으로 설명할 수 있다. 정상 성인의 경우 제시된 조사 '가/이’ 및 ‘을/를' 확인 후 문법 적으로 적절한 단어를 선택하는 것이 가능했을 것이나 실어증 환 자의 경우 조사 처리 능력의 결함으로 조사 단서를 제대로 활용하 지 못해서 적절한 단어를 선택하는 데 더 큰 어려움을 보였을 것으 로 해석된다.

본 연구에서는 동사 선택 과제에는 두 개의 의미역을 제시한 후, 동사를 선택하는 과제이기에 동사 후치어의 특징상, 행동주와 대 상의 두 가지 단서가 모두 동사 앞에 제공되어, 실어증 환자들이 의 미 및 구조적 단서를 활용하여 동사 선택에 높은 수행력을 보일 것 으로 예상하였다. 그러나 연구결과, 실어증 환자 집단이 정상 성인 집단에 비해 여전히 유의하게 낮은 수행력을 보였다. 앞서 언급한 기존 연구결과와 같이(Friederici \& Frazier, 1992; Miyake et al., 1994) 의미역을 이해하여 동사 재인에 성공하기 위해서는 단어들 간의 의 미적, 통사적 수준에서 통합적인 처리 능력이 요구된다. 본 실험에 서 두 개의 의미역을 제공한 것이 실어증 환자들에게는 단서로 작 용하기 보다 오히려 이해의 복잡성을 증가시킨 것이 수행력 저하의 하나의 원인으로 생각해볼 수 있다. Herlofsky와 Edmonds (2013) 의 연구에서 정상 성인을 대상으로 두 개의 명사를 제시한 후 동사 를 처리하는 능력을 살펴보았다. 두 개의 명사 중 동사와 관련된 명 사가 동사 위치 바로 앞에 나올 때는 동사를 처리하는 반응속도가 빨라지지만, 관련된 명사가 무관련 명사 앞에 제시되고, 동사는 무 관련 명사 바로 뒤에 제시될 때는 동사를 처리하는 반응속도가 빠 르게 감퇴하였다. 이러한 결과는 제시되는 명사의 개수보다 동사와 관련된 명사의 위치가 동사와 더 가까이 위치하였을 때 동사 처리 를 촉진할 수 있음을 시사한다. 본 연구에서 실어증 환자들에게 의 
미역 모두를 동사 앞에 제시하였다. 의미역이 모두 동사 앞에 위치 할 수밖에 없는 한국어 특징상, 동사 의미역 위치에 따른 영향에 대 한 해석은 기존 연구와 직접 비교하기 힘들겠지만, 향후 연구에서 는 의미역 제시 개수 및 유형을 함께 조절하였을 때, 한국어 사용 실어증 환자에게 나타나는 현상을 고찰하는 것도 의미가 있을 것 으로 보인다.

실어증 환자들에게 동사를 선택하는 데 영향을 주는 의미역 유 형이 어떤 것인지 상관관계 및 회귀분석을 통해 살펴본 결과, 동사 선택 과제 수행력을 유의하게 예측하는 변수는 대상 의미역인 것으 로 나타났다. 행위자 의미역에서는 동사 선택 과제와 유의한 상관 관계가 관찰되지 않았다. 즉, 실어증 환자가 동사를 선택할 때 영향 을 미치는 의미역은 목적어에 해당하는 명사(대상)인 것으로 나타 났다. 이러한 결과는 실어증 환자들이 의미역을 처리할 때, 동사특정 지식(verb-specific knowledge)에 영향을 받는다고 주장한 Dickey 와 Warren (2015)의 기존 연구와 일치한다. 특히, 한국어의 경우, 목 적어는 주어에 비해 동사와 통사적으로 더 가까운 자리에 위치하 게 되며, 주어 생략 현상까지 더해져서 주어에 비해 목적어에 위치 하는 의미역이 동사 재인에 더 큰 영향을 미칠 수 있다. 즉, 이러한 현상은 동사 선택 수행력이 명사구의 통사적 위치에도 영향을 받 을 수 있음을 의미하며, 일반적인 동사 지식보다 동사와 관련된 특 정 지식 (즉, 통사구조 및 위치)에 더 영향을 받을 수 있다는 주장을 뒷받침하는 결과로 해석된다.

마지막으로, 실어증 환자들의 언어 손상 정도가 동사 및 의미역 처리와 어떠한 관계가 있는지를 살펴보았다. 그 결과, 행위자 의미 역 선택 과제는 실어증 중증도와 상관관계를 보이지 않았으나 대상 의미역 선택 과제는 PK-WAB-R의 하위영역 중 내용전달 영역과 유 의한 상관관계가 나타났다. 마지막으로 동사 선택 과제는 PK-WAB$\mathrm{R}$ 의 하위영역 중 실어증 지수(AQ), 유창성, 내용전달, 이름대기 영 역에서 유의한 상관관계가 나타나 실어증 중증도와 관련된 다양한 지표들과 강한 상관관계를 보였다. 주목할만한 점은 상관관계를 보 인 하위영역이 모두 구어 산출 과제인 것이다. 본 연구의 동사 및 의 미역 선택 과제는 구어 산출을 요구하지 않는 패러다임임에도 불구 하고, 실어증 환자의 구어 산출 능력과 높은 상관관계가 나타난 것 은 흥미로운 결과이다. 특히, 동사 선택 과제가 실어증 환자의 구어 산출 능력과 강한 상관관계를 보인 결과는 의미역 선택 과제에 비 해 동사 선택이 실어증 환자의 구어 산출 능력을 예측할 수 있는 효 율적인 과제가 될 수 있음을 시사한다. 동사 후치어인 한국어 특징 상, 동사는 앞에 나온 문장 성분들을 통합하는 위치에 있는 품사이 다. 즉, 의미역에 비해, 동사 처리에 부가되는 인지적 부담이 더 클 수 있으며, 이러한 특징이 실어증 중증도와 강한 상관관계에 기여
한 중요한 요소로 작용했을 수 있다. 이러한 해석은 동사가 관련 의 미역을 통합하는 역할을 한다는 주장에 근거한다(Edmonds \& Mizrahi, 2011).

동사 및 의미역 선택 과제는 실시 과정이 매우 간단하여, 실어증 환자의 중증도와 관련이 있는 또 다른 심층검사(deep test)로서 동 사 이름대기 과제 등 구어 산출을 요구하는 과제에 비해 임상에서 효율적으로 사용될 수 있다는 장점이 있다. 본 연구에서는 과제가 읽기 형태로 제시되었기 때문에 구어 산출 능력과 직접적인 관련이 있는지 살펴보는 것에는 제한이 있었다. 따라서 이러한 제한점을 보완하는 향후 연구로서, 동사 및 의미역 선택과제 수행력이 명사 및 동사 이름대기 과제와 같이 직접적으로 구어 산출에 의존하는 과제들과 관련이 있는지를 살펴보는 것이 필요하다. 본 연구는 한 국 실어증 환자들을 대상으로 한 동사 관련 기초연구로서, 향후 보 다 다양한 심층 평가항목 개발 및 이를 기초로 한 중재기법 개발에 기여할수 있다는 점에서 의미가 있다.

\section{REFERENCES}

Best, W. (1995). A reverse length effect in dysphasic naming: when elephant is easier than ant. Cortex, 31, 637-652.

Choi, S. J., \& Sung, J. E. (2014). Task-specific and argument structure effects on verb production in normal elderly adults: animation vs. picture comparisons. Journal of Rehabilitation Research, 18, 279-293.

Dickey, M. W., \& Warren, T. (2015). The influence of event-related knowledge on verb-argument processing in aphasia. Neuropsychologia, 67, 63-81.

Edmonds, L. A., \& Mizrahi, S. (2011). Online priming of agent and patient thematic roles and related verbs in younger and older adults. Aphasiology, $25,1488-1506$

Edmonds, L. A., Nadeau, S. E., \& Kiran, S. (2009). Effect of Verb Network Strengthening Treatment (VNeST) on lexical retrieval of content words in sentences in persons with aphasia. Aphasiology, 23, 402-424.

Friederici, A. D., \& Frazier, L. (1992). Thematic analysis in agrammatic comprehension: syntactic structures and task demands. Brain and Language, 42, 1-29.

Herlofsky, S. M., \& Edmonds, L. A. (2013). Activating situation schemas: the effects of multiple thematic roles on related verbs in a continuous priming paradigm. Journal of Psycholinguistic Research, 42, 1-19.

Hong, K. (1998). Idiomatic expressions in Korean and argument structure. Language Research, 34, 547-573.

Hyun, J. M., Kim, H. H., Shin, J. C., \& Seo, S. G. (2003). Retrieval of nouns 
and verbs in Broca's and Wernicke's aphasia. Korean Journal of Communication \& Disorders, 8, 171-187.

Jung, H. W., Choi, S. Y., \& Hwang, M. (2014). Word frequency and length effects on the lexical decisions of adults with anomic aphasia. Communication Sciences \& Disorders, 19, 80-88.

Kang, Y. W., Chin, J. H., Na, D. L., Lee, J. H., \& Park, J. S. (2000). A normative study of the Korean version of Controlled Oral Word Association Test (COWAT) in the elderly. Korean Journal of Clinical Psychology, 19, 385392.

Kang, Y., Na, D. L., \& Hahn, S. (1997). A validity study on the Korean MiniMental State Examination (K-MMSE) in dementia patients. Journal of the Korean neurological association, 15, 300-308.

Kim, G. Y. (2006). Verb production and argument structures in aphasics (Master's thesis). Yonsei University, Seoul, Korea.

Kim, H., \& Na, D. L. (2012). Paradise · Korean version-Western Aphasia Battery $(K-W A B)$ - revised. Seoul: Paradise Welfare Foundation.

Kim, M., \& Thompson, C. K. (2000). Patterns of comprehension and production of nouns and verbs in agrammatism: implications for lexical organization. Brain and Language, 74, 1-25.

Kwag, E. J., Sung, J. E., Kim, Y. H., \& Cheon, H. J. (2014). Effects of verb network strengthening treatment on retrieval of verbs and nouns in persons with aphasia. Communication Sciences \& Disorders, 19, 89-98.

Kwon, J. (2009). Korean syntax. Seoul: Minumsa.

McRae, K., Ferretti, T. R., \& Amyote, L. (1997). Thematic roles as verb-specific concepts. Language and Cognitive Processes, 12, 137-176.

McRae, K., Hare, M., Elman, J. L., \& Ferretti, T. (2005). A basis for generating expectancies for verbs from nouns. Memory \& Cognition, 33, 1174-1184.

Miyake, A., Carpenter, P. A., \& Just, M. A. (1994). A capacity approach to syntactic comprehension disorders: making normal adults perform like aphasic patients. Cognitive Neuropsychology, 11, 671-717.

Nam, K. S. (2004). Modern Korean syntax. Seoul: Taehaksa.

Nam, S. H. (2007). Event structure and argument structure of Korean verb. Seoul: Seoul National University Press.

Park, C. H. (2013). A study of ellipsis in contemporary Korean. Urimal, 32, 39-61.

Saeed, J. I. (1997). Semantics. Oxford: Blackwell Publishers.

Seo, J., Ko, G., Yoo, H., \& Kim, M. (2000). What is a argument structure. Seoul: Worin.

Seo, S. (1998). Word frequency in modern Korean language. Seoul: Language and Information Development Center, Yonsei University.

Sung, J. E. (2011). The reliability and validity of short-term and working memory pointing tasks developed for clinical populations with speech and language disorders. Korean Journal of Communication \& Disorders, 16, 185201.

Sung, J. E. (2016). The effects of verb argument complexity on verb production in persons with aphasia: evidence from a subject-object-verb language. Journal of Psycholinguistic Research, 45, 287-305.

Sung, J. E., Jeong, K. H., Sim, Y. R., Lee, S. E., \& Mo, K. O. (2015). Deficits in processing case markers in individuals with aphasia. Frontiers in Psychology, 6. http://doi.org/10.3389/conf.fpsyg.2015.65.00045.

Wambaugh, J. L., Doyle, P. J., Martinez, A. L., \& Kalinyak-Fliszar, M. (2002). Effects of two lexical retrieval cueing treatments on action naming in aphasia. Journal of Rehabilitation Research and Development, 39, 455-466.

Yang, Y. (2015). Study on the relationship between verb processing and argument structure in patients with Broca's aphasia (Master's thesis). Daegu University, Gyeongsan, Korea. 
Appendix 1. 선정된 동사, 의미역, 문장

\begin{tabular}{llll}
\hline Verb & Agent & Theme & \multicolumn{1}{c}{ Sentence } \\
\hline 읽다 & 이모 & 신문 & 이모가 신문을 읽다. \\
먹다 & 아이 & 빵 & 아이가 빵을 먹다. \\
고치다 & 남자 & 문 & 남자가 문을 고치다. \\
마시다 & 아기 & 우유 & 아기가 우유를 마시다. \\
따다 & 할아버지 & 사과 & 할아버지가 사과를 따다. \\
벗다 & 누나 & 신발 & 누나가 신발을 벗다. \\
닫다 & 형 & 창문 & 형이 창문을 닫다. \\
펴다 & 동생 & 책 & 동생이 책을 펴다 \\
켜다 & 아빠 & 전등 & 아빠가 전등을 켜다. \\
가꾸다 & 할머니 & 꽃 & 할머니가 꽃을 가꾸다. \\
말다 & 언니 & 김밥 & 언니가 김밥을 말다. \\
짓다 & 고모 & 집 & 고모가 집을 짓다. \\
깎다 & 여자 & 참외 & 여자가 참외를 깎다. \\
자르다 & 오빠 & 종이 & 오빠가 종이를 자르다. \\
굽다 & 엄마 & 고기 & 엄마가 고기를 굽다.
\end{tabular}

Appendix 2. 의미역 선택 과제

[행위자 의미역 선택 과제]

\begin{tabular}{|l|l|l|}
\hline \multicolumn{3}{|c|}{ 가 깎다. } \\
\hline 엄마 & 고추 & 기차 \\
\hline
\end{tabular}

[대상 의미역 선택 과제]

\begin{tabular}{|l|l|l|}
\hline \multicolumn{3}{|c|}{ 를 깎다. } \\
\hline 모자 & 상추 & 참외 \\
\hline
\end{tabular}

Appendix 3. 동사 선택 과제

\begin{tabular}{|c|c|c|}
\hline \multicolumn{2}{|c|}{ 엄마가 참외를 } \\
\hline 속이다 & 끄다 & 깎다 \\
\hline
\end{tabular}




\title{
국문초록
}

\author{
의미역 유형에 따른 실어증 환자의 동사 및 의미역 처리 능력과 중증도 간의 관계 \\ 정귀현 $\cdot$ 성지은 \\ ${ }^{1}$ 이화여자대학교 대학원 언어병리학과
}

배경 및 목적: 본 연구는 실어증 환자들의 동사 의미역 처리에서 나타나는 양상을 살펴보며, 실어증 환자들의 의미역 선택 수행력이 실 어증 중증도와 어떠한 관련이 있는지 알아보고자 한다. 방법: 실어증 환자 15 명, 정상 성인 15 명이 연구에 참여하였다. 대상자는 동사와 관련된 의미역을 선택하는 과제(행위자 또는 대상)와 2 가지 의미역이 동시에 제시된 후, 동사를 선택하는 과제를 시행하였다. 결과: 실 어증 환자군이 정상군에 비해 의미역 및 동사 선택 과제에서 어려움을 보였으며, 의미역 유형에 대하여 실어증 환자군과 정상군 모두 행 위자보다 대상을 선택하는 과제에서 더 높은 정반응률을 보였다. 마지막으로, 동사 선택 과제가 실어증 중증도와 관련된 다양한 지표 들과 강한 상관관계를 보였다. 논의 및 결론: 실어증 환자들은 동사를 의미적으로 처리하는 능력에 어려움을 보이며, 한국어의 주어 생 략 특성의 영향을 받아, 행위자 의미역 선택 과제에서 더 큰 어려움을 보인 것으로 해석된다. 이와 같은 이유로 실어증 환자의 동사 선택 과제 수행력을 예측하는 주요 변인은 대상 선택 과제인 것으로 나타났다. 동사 선택 과제가 표준화된 실어증검사 하위항목 중 구어 산 출 과제와 강한 상관관계를 보였다는 점에서, 동사 처리 과제가 한국 실어증 환자의 구어 산출 중증도를 살펴볼 수 있는 심층과제로서 기여할 수 있다는 점에서 임상적 의의가 있다.

핵심어: 실어증, 동사, 의미역, 동사 처리, 증증도

본 논문은 2016년 대한민국 교육부와 한국연구재단의 지원을 받아수행된 연구임(No. NRF-2017R1A2B4006604).

본 논문은 제 1 저자의 석사논문을 발췌 및 수정한 것임.

\section{참고문헌}

강연욱, 나덕렬, 한승혜(1997). 치매환자들을 대상으로 한 K-MMSE의 타당도연구. 대한신경과학회지, 15, 300-308.

강연욱, 진주희, 나덕렬, 이정희, 박재설(2000). 통제 단어 연상 검사(Controlled Oral Word Association Test)의 노인 규준 연구. 한국심리학회지: 임

상, 19, 385-392.

곽은정, 성지은, 김연희, 전희정(2014). 동사의미역강화중재가 실어증 환자의 동사 및 명사 이름대기에 미치는 효과. 언어청각장애연구, 19, 89-98.

권재일(2009). 한국어 통사론. 서울: 민음사.

김가영(2006). 실어증 환자의 동사산출과 논항구조 간의 관계. 연세대학교 대학원 석사학위논문.

김향희, 나덕렬(2012). 파라다이스-한국판-웨스턴실어증검사(개정판). 서울: 파라다이스 복지재단.

남기심(2004). 현대 국어 통사론. 서울: 태학사.

남승호(2007). 한국어 술어의 사건구조와 논항구조. 서울: 서울대학교출판부.

박청희(2013). 주어와서술어의 생략 현상 연구. 우리말연구, 32, 39-61.

서상규(1998). 연세말뭉치 1-9를 대상으로 한 현대한국어의 어휘빈도. 서울: 연세대학교 언어정보개발연구원.

서정곤, 고광주, 유혜원, 김미령(2000). 논항구조란 무엇인가. 서울: 월인.

성지은(2011). 말언어장애군의 단기기억 및 작업기억용량 측정을 위한 지시하기과제 개발 예비 연구: 재검사 신뢰도 및 타당도. 언어청각장애연구, 16,

185-201.

양유미(2015). 브로카실어증 환자의 동사처리와 논항구조 간의 관계. 대구대학교 대학원 석사학위논문.

정혜원, 최소영, 황민아(2014). 명칭 실어증 환자의 어휘 판단에서 단어 빈도 및 길이 효과. 언어청각장애연구, 19, 80-88.

최수진, 성지은(2014). 과제 제시 유형 및 논항 수에 따른 노년층의 동사 이름대기 수행력 차이. 재활복지, 18, 279-293.

현정문, 김향희, 신지철, 서상규(2003). 베르니케 실어증과 브로카 실어증 환자들의 명사와 동사 인출 비교. 언어청각장애연구, 8, 171-187.

홍기선(1998). 한국어 관용어구와 논항구조. 어학연구, 34, 547-573. 